\title{
Effect of Social Isolation on Rat Ovary and the Possible Protective Role of Melatonin: Light, Electron Microscopic, Biochemical and Molecular Study
}

\author{
DOAA MAHMOUD SHUAIB, M.D.* and BAHAA ELDIN ALI KHALID, M.D.**** \\ The Department of Anatomy \& Embryology, Faculty of Medicine, Cairo University, Egypt* and \\ The Department of Anatomy, College of Medicine, Jouf University, Saudi Arabia**
}

\begin{abstract}
Background: Social Isolation (SI) is an influential stressor in animals and humans, which has a negative impact on mental and physical health. It is associated with increased oxidative stress and decreased antioxidant capacity. Melatonin (MT) is well known by its antioxidant properties that help in prevention of tissue damage.

Aim of Study: The present study aimed to investigate the harmful effect of SI on rat ovary and the possible protective role of MT.

Material and Methods: Twenty adult female albino rats were divided into four groups; five rats in each (control, MT, SI and SI + MT). Histological examination was done using hematoxylin and eosin, semithin sections were stained with toluidine blue and ultrathin sections were performed. Measurements of Malondialdehyde (MDA) and Superoxide Dismutase (SOD) activity in ovarian tissue were carried out. Quantitative analysis of SIRT1 gene expression was done by real-time Polymerase Chain Reaction (PCR). Morphometric measurements were also performed.
\end{abstract}

Results: Light microscopic examination of ovarian follicles from SI group showed shrunken granulosa cells with pyknotic nuclei and irregular oocytes with rarified cytoplasm. Cytoplasmic vacuolation was observed in granulosa cells, theca cells and granulosa lutein cells. Ultrastructural examination of granulocsa cells showed swollen mitochondria and abundant lipid droplets. The oocytes exhibited disrupted microvilli. There was significant decrease in the mean follicular diameter, granulosa and theca layer thickness in SI group compared to control group. These morphological changes were associated with significant increase in MDA and decrease in SOD activity, in addition to increased SIRT1 gene expression. Concomitant administration of MT improved the previously mentioned alterations.

Conclusion: Social isolation induced histological, ultrastructural and morphometric changes in the ovary of rats. These changes were associated with oxidative stress, decreased antioxidant capacity and increased SIRT1 gene expression.

Correspondence to: Dr. Doaa Mahmoud Shuaib, E-Mail: doaa.shuaib@kasralainy.edu.eg
Melatonin administration ameliorated these harmful effects, possibly due to its antioxidant property.

Key Words: Ovary - Follicles - Social isolation - Melatonin - Antioxidant.

\section{Introduction}

DEMOGRAPHIC changes are responsible for increased prevalence of loneliness and Social Isolation (SI) in modern community. Social isolation is defined as an objective reduced or absent social connections [1]. It is considered as a psychosocial stressor and a key factor in the development of psychiatric problems $[2,3]$. It was reported that social interaction improves both mental and physical health [4]. Moreover, social rehabilitation might be necessary for effective treatment of psychiatric disorders [3].

Several studies were carried out to understand the negative impact of SI and to investigate how it alters the psychological and physiological mechanisms in animals and humans [5] . Serra et al. [6] reported that socially isolated rats immediately after weaning, in the absence of other stressful stimuli, reduced the brain and plasma concentrations of two neuroactive steroids responsible for sedation and alleviation of anxiety. Ren et al. [2] pointed out that SI has been well known as a rodent animal model of depression. Moreover, ZanierGomes et al. [7] studied the vulnerability to depression in female rats and found that SI for three weeks induced depressive behavior. In humans, the mechanisms are poorly understood but clear that anxiety, depression and schizophrenia might be caused by environmental factors similar to SI [8]. 
It was emphasized that there is an association between SI and increased oxidative stress [9] Oxidative stress has been related to decreased progesterone level and poor follicle quality, which leads to impaired ovarian function and decreased fertility [10]. The sirtuins (SIRTs) family is a group of enzymes that have been linked to oxidative stress-related processes; including mitochondrial function and repair of DNA damage [11]. Silent Information Regulator Type 1 (SIRT1); the most extensively studied member of the sirtuin family, plays a curial role in reducing oxidative stress and protection of cells from Reactive Oxygen Species (ROS) [12] .

Melatonin (MT) is an endogenous hormone that is secreted from the pineal gland in darkness. It regulates several biological functions such as sleep, circadian rhythm and reproduction. Moreover, is protects the tissue from oxidative damages by stimulation of antioxidant enzymes [13].

In the reviewed literature, studies concerning the effect of SI on the ovary were lacking. Therefore, the aim of this study was to assess the histological, ultrastrcucural, biochemical and molecular changes in the ovary of socially isolated rats and the possible ameliorative role of MT.

\section{Material and Methods}

The study was done in the Faculty of Medicine, Cairo University from December 2017 to April 2019.

\section{Animals:}

Twenty adult female albino rats of Sprague Dawley strain with regular estrous cycle aged three to five months $(150-200 \mathrm{~g})$ were obtained from the Animal House, Faculty of Medicine, Cairo University. The experiment was carried out in agreement with guidelines of Cairo University of Medical Sciences for care and use of laboratory animals. Upon arrival, rats were housed in groups 2-4 per cage in standard stainless steel cages with galvanized iron wires and left for one week for acclimatization, animals were fed on standard rat chow diet and supplied water ad libitum. They were maintained in the normal daily light and dark cycle at a constant temperature of $23 \pm 2^{\circ} \mathrm{C}$ and $65 \%$ humidity. All experimental procedures were performed between 08:30h and noon.

\section{Chemicals:}

Melatonin was obtained in the form of powder from Amoun Pharmaceutical Industries Co., Cairo,
Egypt. It was dissolved in a small amount of ethanol and diluted in saline (5-95\%) [14].

\section{Sample size calculation:}

Sample size was calculated based on a pilot study of three rats in each group; the difference between cases and controls in ovarian malondialdehyde was $4.3 \pm 2.1$. Five rats were needed in each group to achieve power $80 \%$ and $5 \%$ significance level. Sample size calculation was achieved using PS: Power and Sample Size Calculation software Version 3.1.2 (Vanderbilt University, Nashville, Tennessee, USA).

\section{Experimental design:}

The rats were divided into four groups (five rats in each) as follows:

- Group A (control group): The rats were kept in the previously mentioned conditions and housed as a group in a cage $(50 \times 28 \times 16 \mathrm{~cm})$ for six weeks.

- Group B (MT group): They were kept in the same conditions as control group for six weeks and received daily intraperitoneal injection of MT at a dose of $5 \mathrm{mg} / \mathrm{kg}$ body weight [14]

- Group C (SI group): They were kept under the previously mentioned conditions and housed in a separate cage for each rat $(32 \times 18 \times 15 \mathrm{~cm})$ beyond smelling and hearing distance from the other rats for six weeks [15].

- Group D (SI + MT treatment $)$ : The same conditions as SI group and received daily intraperitoneal injection of MT at a dose of $5 \mathrm{mg} / \mathrm{kg}$ body weight for six weeks.

\section{Methods:}

At the end of the experiment, the weight of each animal was obtained just before scarification. The animals were euthanized by cervical dislocation under conditions of minimal stress. Rats were subjected to laparotomy and both ovaries of each rat were dissected out.

\section{A- Determination of ovary weight:}

The weight of each dissected ovary was obtained using an electric balance.

\section{$B$ - Biochemical assay:}

1- Measurement of malondialdehyde (MDA) activity: Malondialdehyde is an oxidative stress marker. It was measured in tissue homogenate according to Tipple and Rogers [16]. Pieces from left ovaries $(100 \mathrm{mg})$ were homogenized in $1 \mathrm{~mL}$ of PBS, PH 7.0 with a micropestle in a microtube. 
Trichloroacetic acid (20\%) was added to tissue homogenate to precipitate the protein and centrifuged. Supernatants were collected and thiobarbituric acid solution $(0.8 \%)$ was added to the supernatants. After boiling for 10 minutes in water bath, the absorbance was measured at $405 \mathrm{~nm}$. Concentration of MDA in supernatants of homogenate was calculated using the standard curve.

2- Measurement of Superoxide Dismutase (SOD) activity: The superoxide dismutase is an antioxidant stress marker. Measurement of the activity of SOD in tissue homogenate was done according to Weydert and Cullen [17]. Reduction of nitroblue tetrazolium was inhibited by $\mathrm{O}_{2}$, which is generated by the xanthine/xanthine oxidase system. One unit is the amount of SOD that inhibits the rate of formazan dye formation by $50 \%$.

3- Quantitative analysis of SIRT1 gene expression by real-time Polymerase Chain Reaction
$(P C R)$ : Extraction of total RNA from the homogenized ovarian tissue was done using SV Total RNA Isolation System (Promega, Madison, WI, USA) according to the instructions of the manufacturer. An ultraviolet spectrophotometer was used to measure RNA purity and concentration. Synthesis of complementary cDNA from RNA was done by SuperScript $\rightarrow$ III First-Strand Synthesis System as described in the protocol of the manufacturer (\#K1621, Fermentas, Waltham, MA, USA). An applied Biosystem instrument with software version 3.1 (StepOne TM, USA) measured amplification and analysis of real-time PCR. Gene-specific primer pairs were designed with Gene Runner Software (Hasting Software, Inc., Hasting, NY) from RNA sequences from the gene bank. Calculation of SIRT1 gene expression was calculated using the comparative $\mathrm{Ct}$ method. The values were normalized to beta actin and reported as fold change (Table 1).

Table (1): The primer sequences for the studied genes.

\begin{tabular}{lll}
\hline Isoform & Forward primer & Reversed primer \\
\hline SIRT1 & 5' $^{\prime}$-GGCTCTTGTGCCTATCCC-3' & 5'-CCATTCTGACCCACTTCCTC-3' $^{\prime}$ \\
П-actin & 5'-GGTCGGTGTGAACGGATTTGG-3' $^{\prime}$ & 5'-ATGTAGGCCATGAGGTCCACC-3' $^{\prime}$ \\
\hline
\end{tabular}

SIRT1: Silent Information Regulator Type 1.

\section{C- Light microscopic examination:}

The right ovaries of all groups were fixed in $10 \%$ buffered formaline overnight at room temperature, dehydrated in alcohol, cleared in xylol and embedded in paraffin. Sections of $5 \gamma \mathrm{m}$ thickness were cut and subjected to hematoxylin and eosin (H \& E) stain [18].

\section{D- Electron microscopic examination:}

Pieces from the left ovaries were subjected to ultrastructural examination through preparation of semithin sections (stained with toluidine blue) and ultrathin sections stained with uranyl acetate and lead citrate [19]. The sections were examined and photographed by JEOL JEM 1010 Transmission Electron Microscope (TEM) in the Electron Microscope Research Laboratory, Faculty of Agriculture Research Center, Cairo University.

\section{E-Morphometric measurements in $H \& E$ stained sections:}

1- Diameter of antral follicles: Ovarian follicles were categorized as described by Ahmadi et al. [20] into primordial follicles (single layer of flat cells surrounding the oocyte), primary follicles (single layer of cuboidal cells surrounding the oocyte), preantral follicles (two or more layers of granulosa cells with no visible space between the cells), antral follicles (multiple or single fluid filled spaces between the granulosa cells) and corpus luteum.

The diameter of antral follicles was measured (in $\gamma \mathrm{m}$ ) in 3-10 follicles per ovary, in five ovaries per experimental group (graafian follicles were not included in the measurements). The diameter was recorded as the longest distance along a straight line between opposite follicle edges that passes through the oocyte [21]

2- Granulosa and theca cell thickness in antral follicles: Granulosa and theca cell thickness in antral follicles was measured (in $\gamma \mathrm{m}$ ) in 3-10 follicles per ovary, in five ovaries per experimental group [21].

Photomicrographs of the different groups were taken at magnification X100 using Leica ICC50 microscope equipped with digital camera. Morphometric analysis was done using Image $\mathbf{J}$ image analysis software.

\section{Statistical analysis:}

Statistical analysis was performed using statistical package for the social sciences statistical software (SPSS) version 23.0 (IBM Corporation, Somers, NY, USA). The data was expressed as means \pm Standard Deviation (SD). Statistical data 
was compared using one-way analysis of variance (ANOVA). Any significant ANOVA was followed by post hoc Tukey test to detect which pairs of groups caused the significant difference. Significance was considered when the $p$-value was less than 0.05 .

\section{Results}

A- Body weight and ovary weight:

Non-significant difference was observed in both mean body weight and ovary weight between the four groups (Table 2).

Table (2): Mean body weight and ovary weight in different groups.

\begin{tabular}{lllllll}
\hline \multirow{2}{*}{ roup } & \multicolumn{3}{c}{ BW $(\mathrm{g})$} & \multicolumn{3}{c}{ OW $(\mathrm{g})$} \\
\cline { 2 - 7 } & Mean $\pm \mathrm{SD}$ & Versus & $p$-value & Mean $\pm \mathrm{SD}$ & Versus & $p$-value \\
\hline Control & $165.8 \pm 10.85$ & & & $0.54 \pm 0.06$ & & \\
MT & $169.4 \pm 8.11$ & Control & 0.940 & $0.53 \pm 0.07$ & Control & 0.997 \\
& & SI & 0.506 & & SI & 0.997 \\
& & SI + M & 0.617 & & SI + M & 0.874 \\
SI & \multirow{2}{*}{$160.4 \pm 11.08$} & Control & 0.829 & $0.54 \pm 0.04$ & Control & 1.000 \\
& & MT & 0.506 & & MT & 0.997 \\
& & SI + M & 0.997 & & SI + M & 0.776 \\
SI + MT & $161.6 \pm 9.76$ & Control & 0.909 & $0.5 \pm 0.07$ & Control & 0.776 \\
& & MT & 0.617 & & MT & 0.874 \\
& & SI & 0.997 & & SI & 0.776 \\
\hline
\end{tabular}

BW: Body Weight. OW: Ovary Weight.

Other abbreviations - see text.

\section{B- Oxidative/antioxidative markers in ovarian} tissue:

The mean MDA level showed significant increase in SI group compared to control and MT groups. In SI + MT group; there was significant decrease in the mean MDA in comparison to SI group. The mean MDA showed significant increase in SI + MT group compared to control and MT groups (Table 3 ).

The mean SOD level showed significant decrease in SI group compared to control and MT groups, while in SI + MT group, there was significant increase in the mean SOD compared to SI group. The mean SOD showed significant decrease in SI + MT group compared to control and MT groups (Table 3 ).

\section{C- Determination of SIRT1 gene expression in ovarian tissue:}

Significant increase in SIRT1 gene expression was observed in the ovaries of rats in SI group compared to control and MT groups. The SI + MT group showed significant decrease in SIRT1 gene expression compared to SI group. Gene expression of SIRT1 showed non-significant difference in SI + MT group when compared to control and MT groups (Table 3).

Table (3): Mean level of oxidative/antioxidative markers and SIRT1 gene expression in the different groups.

\begin{tabular}{llllllllll}
\hline \multirow{2}{*}{ Group } & \multicolumn{3}{c}{ MDA } & \multicolumn{3}{c}{ SOD } & \multicolumn{3}{c}{ SIRT1 gene expression } \\
\cline { 2 - 10 } & Mean \pm SD & Versus & $p$-value & Mean \pm SD & Versus & $p$-value & Mean \pm SD & Versus & $p$-value \\
\hline Control & $9.93 \pm 2.87$ & & & $3.08 \pm 0.33$ & & & $1.01 \pm 0.01$ & \\
MT & $8.8 \pm 2.19$ & Control & 0.988 & $3.34 \pm 0.46$ & Control & 0.710 & $1.01 \pm 0.01$ & Control & 0.1000 \\
& & SI & $0.000^{*}$ & & SI & $0.000^{*}$ & & SI & $0.000^{*}$ \\
& & SI + M & $0.002^{*}$ & & SI + M & $0.005^{*}$ & & SI + M & 0.061 \\
SI & $59.98 \pm 8.38$ & Control & $0.000^{*}$ & $0.84 \pm 0.32$ & Control & $0.000^{*}$ & $5.88 \pm 1.26$ & Control & $0.000^{*}$ \\
& & MT & $0.000^{*}$ & & MT & $0.000^{*}$ & & MT & $0.000^{*}$ \\
& & SI + M & $0.000^{*}$ & & SI + M & $0.000^{*}$ & & SI + M & $0.000^{*}$ \\
SI + MT & $24.4 \pm 6.16$ & Control & $0.004^{*}$ & $2.36 \pm 0.4$ & Control & $0.041 *$ & $2.14 \pm 0.3$ & Control & 0.061 \\
& & MT & $0.002^{*}$ & & MT & $0.005^{*}$ & & MT & 0.061 \\
& & SI & $0.000^{*}$ & & SI & $0.000^{*}$ & & SI & $0.000^{*}$ \\
\hline
\end{tabular}

*: $p$-value significant; other abbreviations - see text. 


\section{D- Light microscopic results:}

1- Group A (control group): Histological examination of $\mathrm{H} \& \mathrm{E}$ stained sections of control and MT groups showed similar findings. The ovary was formed of outer cortex and inner medulla. The cortex contained multiple ovarian follicles at different stages of development as well as corpora lutea. The medulla was formed of connective tissue stroma containing numerous blood vessels. The surface of the ovary was covered by germinal epithelium (Fig. 1a). The granulosa cells were
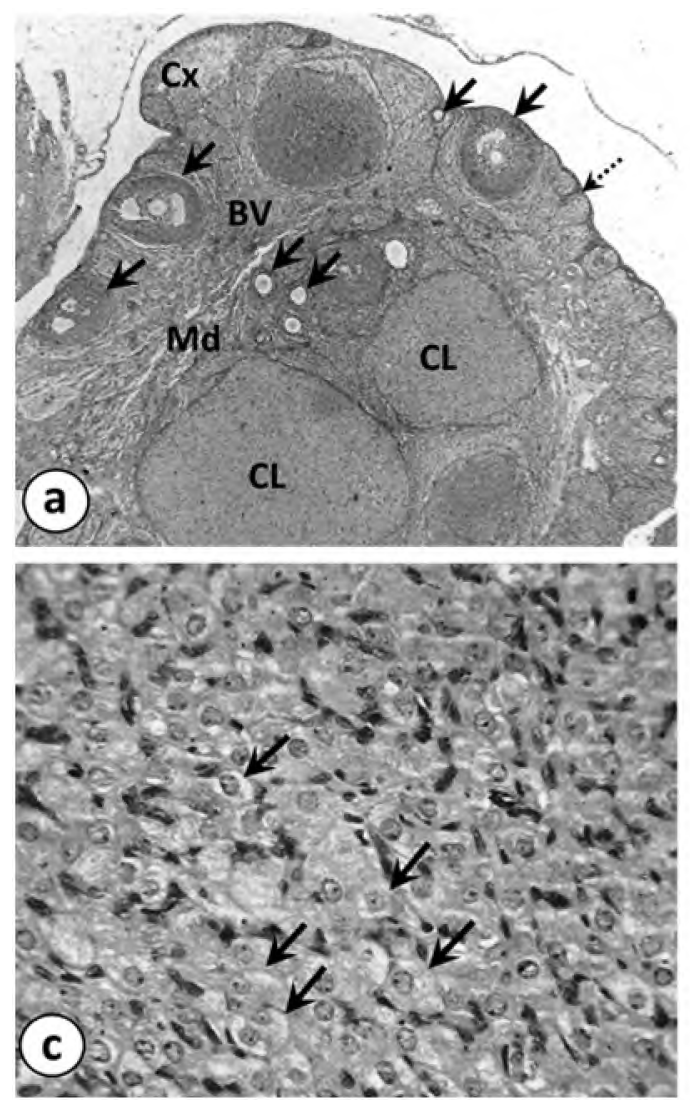

polyhydral with a slightly basophilic cytoplasm and were surrounded by regular flat theca. The oocyte showed pale eosinophilic cytoplasm and large central nucleus. It was surrounded by intact zona pellucida and overlying corona radiata (Fig. $1 b)$. The granulosa lutein cells of corpora lutea were characterized by pale cytoplasm and centrally located nuclei (Fig. 1c). In semithin sections, the granulosa cells exhibited large dark blue rounded or oval nuclei surrounded by a rim of pale blue cytoplasm (Fig. 1d).
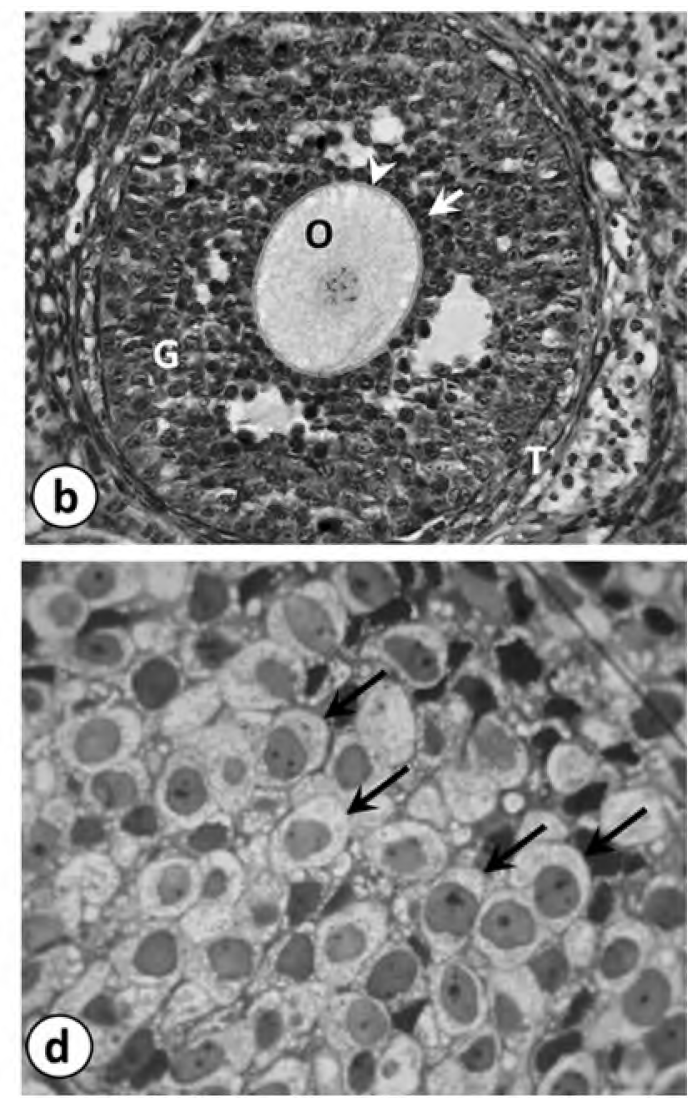

Fig. (1): Photomicrographs of sections of the ovary of adult female albino rat from control group:

(a) The ovary is formed by outer cortex $(\mathrm{Cx})$ and inner medulla (Md). The cortex contains multiple ovarian follicles at different stages of development (arrows) and corpora lutea (CL). The medulla shows blood vessels (BV). The germinal epithelium is illustrated (dotted arrow) (H \& E X40).

(b) Antral follicle shows granulosa cells $(\mathrm{G})$ surrounded by regular flat theca $(\mathrm{T})$. The oocyte $(\mathrm{O})$ is surrounded by intact zona pellucida (arrow head) with overlying corona radiata (arrow) (H \& E X400).

(c) Granulosa lutein cells show pale cytoplasm and central lylocated nuclei (arrows) (H \& E X400).

(d) Semithin section shows granulosa cells with large dark blue nuclei surrounded by a rim of pale blue cytoplasm (arrows) (Toludine blue X1000).

2- Group C (SI group): Examination of ovarian tissue from this group showed degenerated follicles. The granulosa cells were shrunken with dark pyknotic nuclei and some granulosa cells were seen floating in the antrum. The oocytes were irregular in shape, shrunken and the zona pellucida was thin and interrupted. They were surrounded by incomplete ring of corona radiata and separated from it by a space (Fig. 2a). Cytoplasmic vacuolation of granulosa and theca cells was also encountered (Fig. 2b). The oocytes of some follicles appeared with faint rarified cytoplasm (Fig. 2c). The granulosa lutein cells showed cytoplasmic vacuoles pushing their nuclei peripherally (Fig. 2d). Corpora lutea were surrounded by dilated and congested blood vessels (Fig. 2e). Semithin section showed widely separated granulosa cells with dark nuclei and vacuolated cytoplasm (Fig. 2f). 

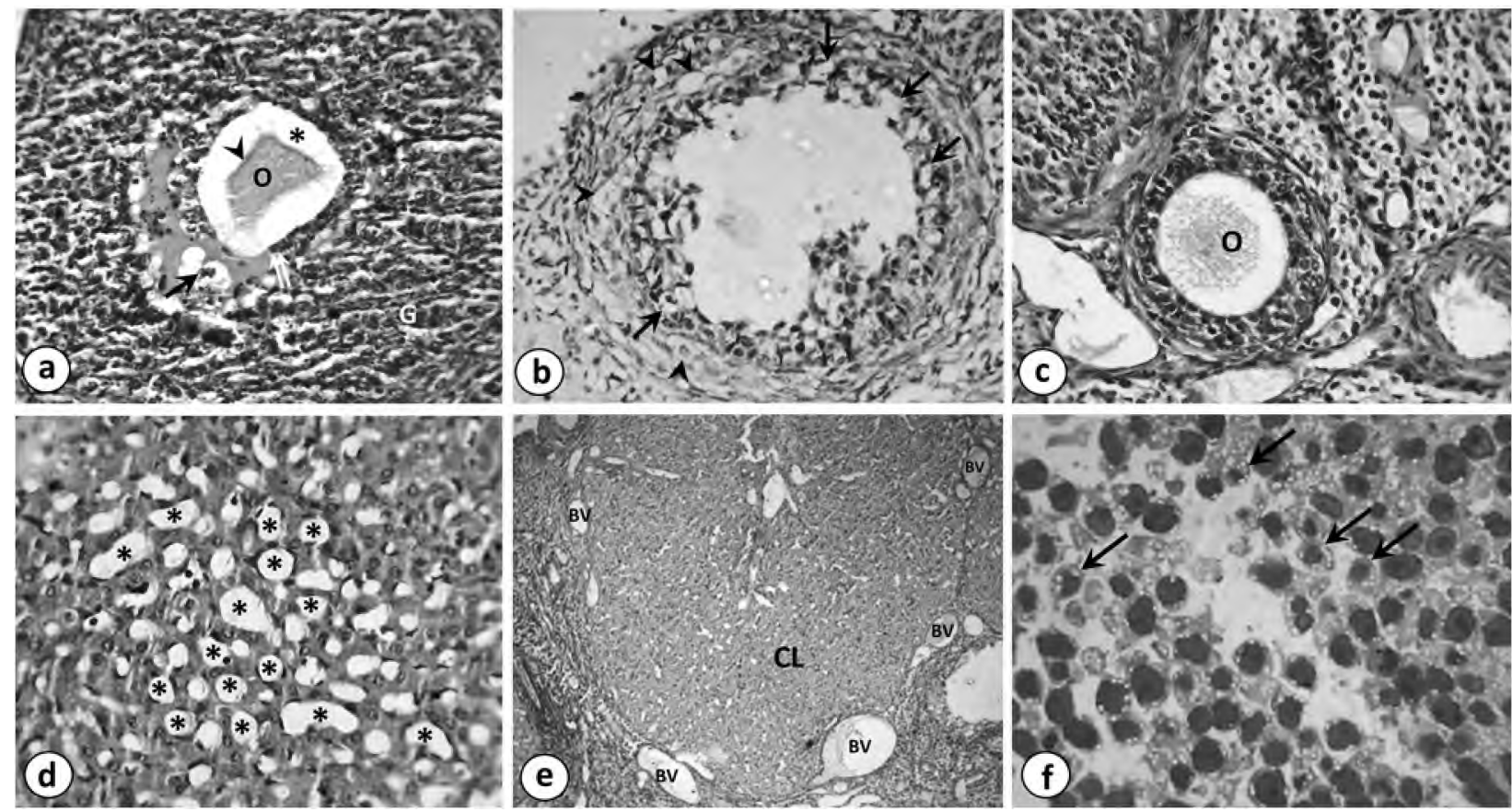

Fig. (2): Photomicrographs of sections of the ovary of adult female albino rat from SI group:

(a) Antral follicle shows shrunken granulosa cells (G). Some granulosa cells are seen floating in the antrum (arrow). The oocyte $(\mathrm{O})$ is irrigular and the zona pellucida (arrow head) is thin and interrupted. It is surrounded by incomplete ring of corona radiata (double arrows) and separated from it by space (asterik) (H\&E X400).

(b) Antral follicle shows vacuolation of granulosa cells (arrows) and theca cells (arrow heads) (H\&E X400).

(c) Preantral follicle shows oocyte $(\mathrm{O})$ with faint esinophilic rarified cytoplasm (H\&E X400).

(d) Granulosa lutein cells show several cytoplasmic vacuoles pushing the nuclei peripherally (astericks) (H\&E X400).

(e) Corpus luteum (CL) is surrounded by multiple congested blood vessles (BV) (H\&E X100).

(f) Semithin section shows granulosa cells with pyknotic nuclei and vacuolated cytoplasm (arrows) (Toludine blue X1000).

3- Group D (SI + MT group): Histological examination of the ovarian follicles from this group showed improvement in their morphology. The Granulosa and theca cells displayed regular and intact organization; however, some granulosa cells were dark with pyknotic nuclei. The oocyte was apparently normal (Fig. 3a). The granulosa lutein cells of corpora lutea showed normal morphology. Few cells showed vacuolation of their cytoplasm and dark pyknotic nuclei (Fig. 3b). The blood vessels which surrounded the corpora lutea were not congested (Fig. 3c). Toludine blue stained semitin sections showed well-organized granulosa cells, however, some nuclei were shrunken \& pyknotic (Fig. 3d).

\section{E- Electron microscopic results:}

1- Group A (control group): By electron microscope, the granulosa cells were tightly packed and showed large rounded or oval euchromatic nuclei surrounded by regular nuclear membrane. The cytoplasm of granulosa cells showed welldeveloped mitochondria, intact rough endoplasmic reticulum and free ribosomes (Fig. 4a,b). The oocyte contained abundant mitochondria, ribosomes and fibril lamellae. It was surrounded by intact zona pellucida which showed oocyte microvilli and granulosa cells processes (Fig. 4a,c).

2- Group C (SI group): Ultrastructural examination of ovarian tissue from this group showed degenerated granulocsa cells with irregular indented nuclei and dissolution of chromatin (karyolysis). The intercellular spaces between granulosa cells were expanded. Dark apoptotic bodies and abundant lipid droplets were observed (Fig. 5a). Heterolysosomes with electron dense and electron lucent contents as well as numerous swollen mitochondria with disrupted cristae were seen (Fig. 5b). The corona radiata cells showed irregular nuclei and the oocyte exhibited vacuolated cytoplasm and disrupted microvilli (Fig. 5c).

3- Group D (SI + MT group): Electron microscopic examination showed improvement in the ultrastructure of ovarian follicles. The granulosa cells showed regular nuclei and intact mitochondria, ribosomes and well-developed rough endoplasmic reticulum. Few granulosa cells exhibited ballooned 
mitochondria, lysosomes, expanded intercellular spaces and irregular nuclei (Fig. 6a-c). The oocytes contained intact organelles, apart from few swollen
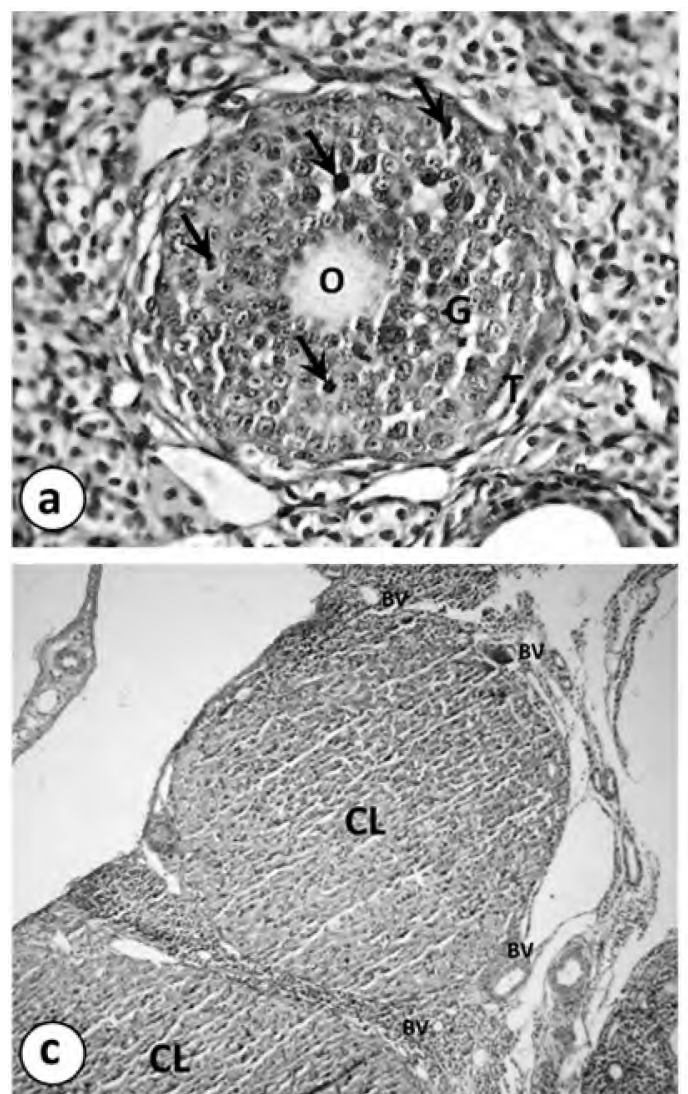

mitochondria. They were surrounded by intact zona pellucida which showed oocyte microvilli (Fig. $6 c)$.
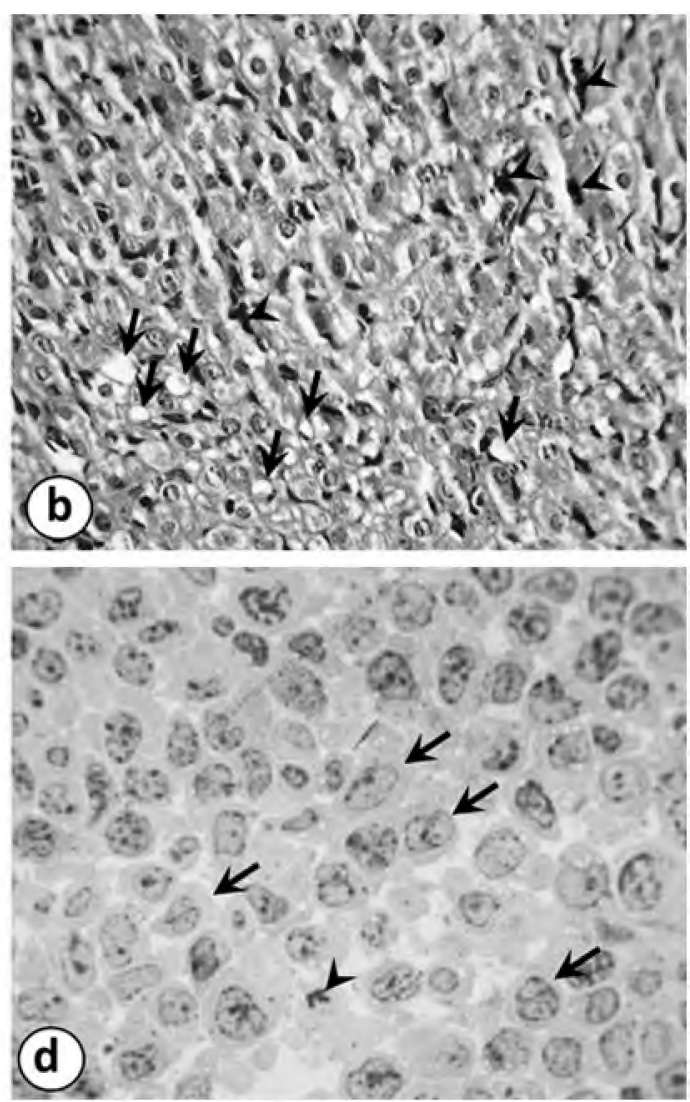

Fig. (3): Photomicrographs of sections of the ovary of adult female albino rat from SI + MT group:

(a) Prentral follicle shows apparantly normal granulosa cells $(\mathrm{G})$, theca cells $(\mathrm{T})$ and oocyte $(\mathrm{O})$. Few granulosa cells exhibit dark pyknotic nuclei (arrows) (H \& E X400).

(b) Granulosa lutein cells of corpus luteum are apparently normal. Few cells show cytoplasmic vacuolation (arrows) and dark pyknotic nuclei (arrow heads) (H \& E X400).

(c) The blood vessels (BV) which surround the corpora lutea (CL) are not congested (H \& E X100).

(d) Semithin section shows apparently nomal granulosa cells (arrows). Few pyknotic nuclei are demonstrated (arrow head) (Toludine blue X1000).
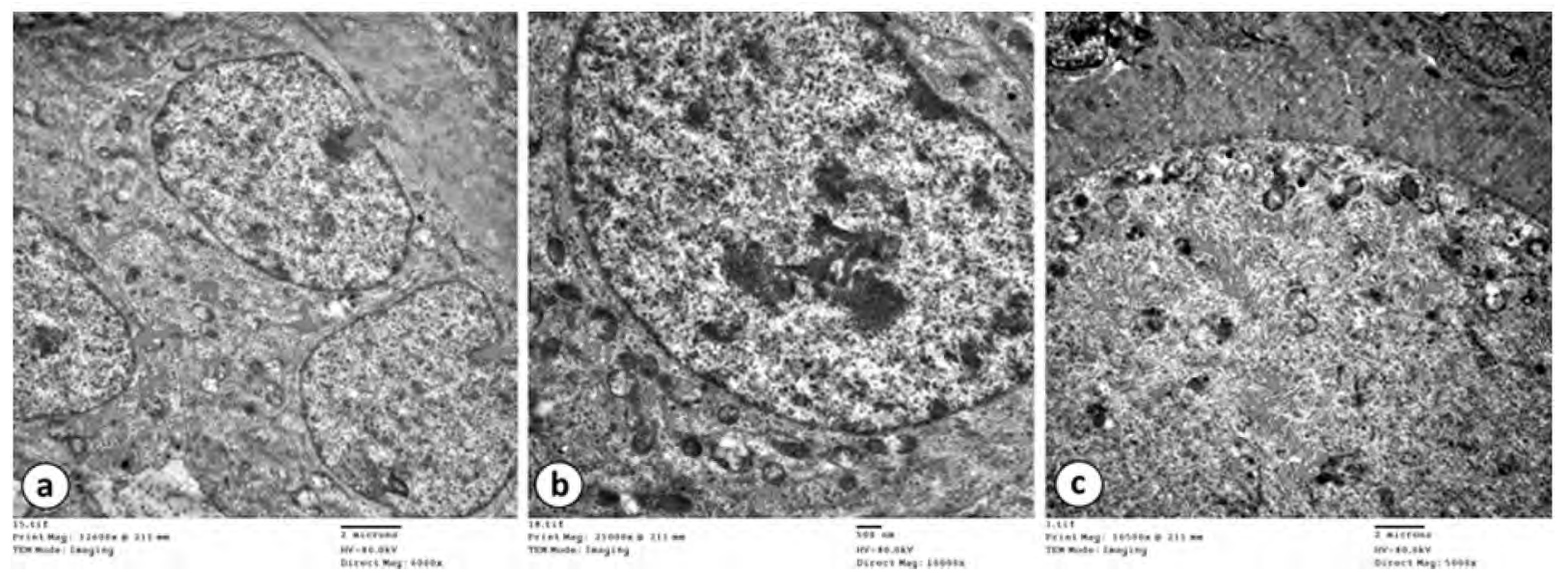

Fig. (4): Electron photomicrographs of sections of the ovary of adult female albino rat from control group:

(a) The granulosa cells are thighly packed (arrow heads). They show regular euchromatic nuclei (arrows) and abandant mitochondria $(\mathrm{m})$. Intact zona pellucida $(\mathrm{Zp})$ and oocyte $(\mathrm{O})$ are illustrated (X6000).

(b) Granulosa cell shows regular euchromatic nucleus (n), well-developed mitochondria (m), rough endoplasmic reticulum (arrow head) and free ribosomes (r) (X10000).

(c) The oocyte contains well-organized organelles as mitochondtia (m), free ribosomes (r) and fibril lamellae (arrows). It is surrounded by intact zona pellucida $(\mathrm{Zp})$, which contains oocyte microvilli (asteriks) and granulosa cells processes (arrow head) (X5000). 

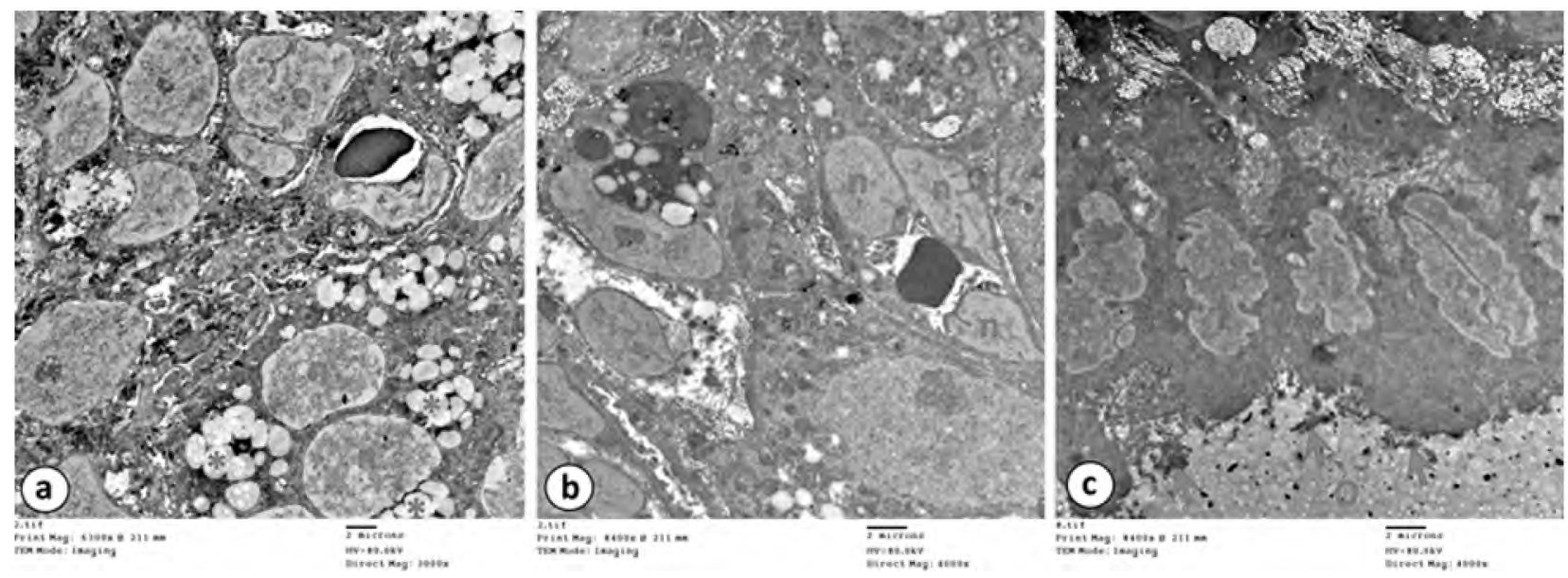

Fig. (5): Electron photomicrographs of sections of the ovary of adult female albino rat from SI group:

(a) The granulosa cells show irrigular nuclei (arrow heads) and karyolsis (n). An electron dense body surrounded by a space and indenting the nucleus of the neiboring cell (apoptotic body) is shown (arrow). Numeorus lipid droplets are illustated (asteriks). The gaps between the granulosa cells are expaneded (double arrow) (X3000).

(b) The granulosa cells show irrigular nuclei (n) and swollen mitochondria with disrupted cristae (m). Large heterolysosomes containing electron dense and electron lucent contents are demonstrated (arrows) (X4000).

(c) The corona radiata shows irrigular nuclei $(\mathrm{n})$. The oocyte $(\mathrm{O})$ exhibits vacuolated cytoplasm and disrupted microvilli (arrows) (X4000).
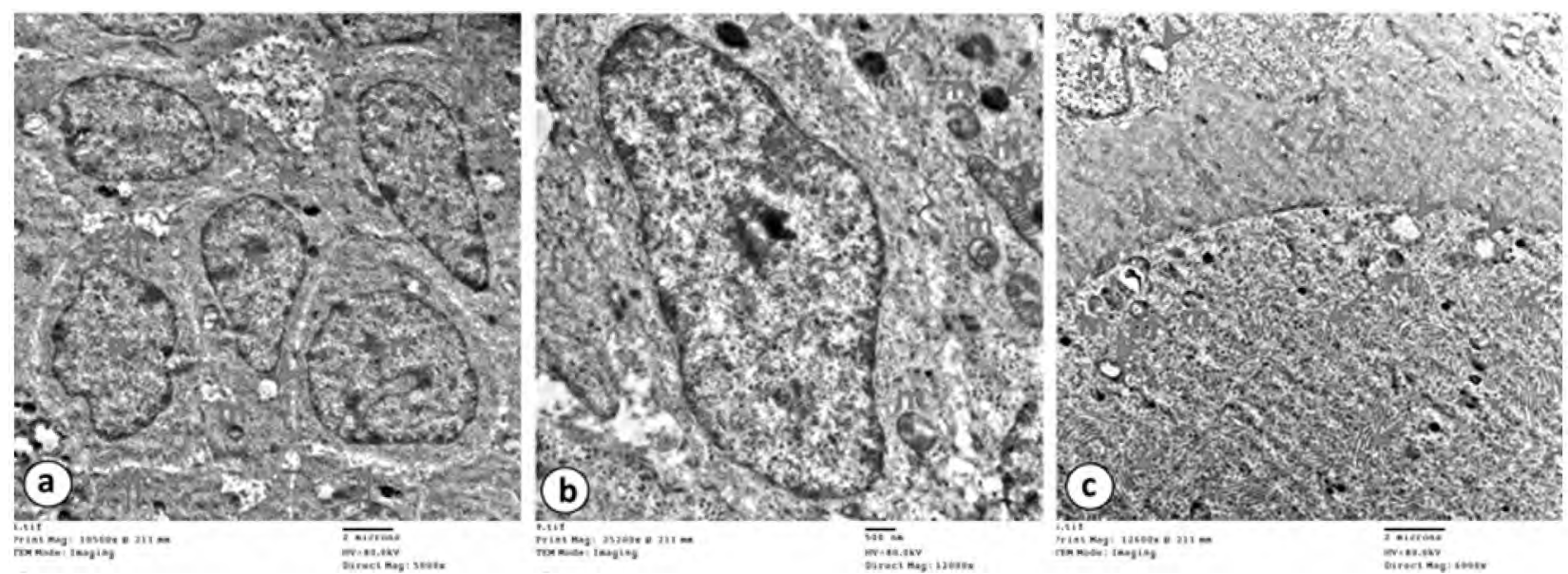

Fig. (6): Electron photomicrographs of sections of the ovary of adult female albino rat from SI + MT group:

(a) The granulosa cells show regular nuclei (n) and intact mitochondria (m). Few swollen mitocndria are illustrated (arrow heads). The gaps between the granulosa cells are expaneded (double arrows) (X5000).

(b) Granulosa cell shows euchromatic nucleus (n), well-developed abundant mitochondria (m), intact rough endoplasmic reticulum (arrow head) and free ribososmes (r). Few lysosomes are illustrated (arrows) (X12000).

(c) The oocyte shows well-developed mitochondtia (m), fibril lamellae (arrows) and surrounded by intact zona pellucida (Zp) with microvilli (asteriks). Few ballooned micthondria are demontrated in the cytoplsam of the oocyte and granulosa cells (arrow heads). Irrigular granulosa nucleus is shown (n) (X6000).

\section{F- Morphometric results:}

1- Diameter of antral follicles: The mean diameter of antral follicles showed significant decrease in SI group compared to control and MT groups. In SI + MT group; there was significant increase in the mean antral follicular diameter compared to SI group. The mean antral follicle diameter showed non-significant difference in SI + MT group when compared to control and MT groups (Table 4 ).
2- Granulosa thickness and theca layer thickness in antral follicles:

The mean granulosa and theca thickness showed significant decrease in SI group compared to control and MT groups. There was significant increase in the mean granulosa and theca thickness in SI + MT group compared to SI group. The SI + MT group showed significant decrease in the mean granulosa and theca thickness compared to control and MT groups (Table 4). 
Table (4): Mean follicular diameter, granulosa thickness and theca thickness of antral follicles in different groups.

\begin{tabular}{|c|c|c|c|c|c|c|c|c|c|}
\hline \multirow{2}{*}{ Group } & \multicolumn{3}{|c|}{ FD $(\mathrm{m})$} & \multicolumn{3}{|c|}{ GTh $\left(\mathrm{m}^{\mathrm{m}}\right)$} & \multicolumn{3}{|c|}{ TTh $(\mathrm{m})$} \\
\hline & Mean \pm SD & Versus & $p$-value & Mean \pm SD & Versus & $p$-value & Mean \pm SD & Versus & $p$-value \\
\hline Control & $478.29 \pm 94.45$ & & & $147.67 \pm 9.58$ & & & $49.02 \pm 5.26$ & & \\
\hline MT & $490.69 \pm 49.01$ & $\begin{array}{l}\text { Control } \\
\text { SI } \\
\text { SI }+\mathrm{M}\end{array}$ & $\begin{array}{l}0.988 \\
0.000^{*} \\
0.276\end{array}$ & $141.82 \pm 8.07$ & $\begin{array}{l}\text { Control } \\
\text { SI } \\
\text { SI }+\mathrm{M}\end{array}$ & $\begin{array}{l}0.725 \\
0.000^{*} \\
0.020^{*}\end{array}$ & $46.6 \pm 3.21$ & $\begin{array}{l}\text { Control } \\
\text { SI } \\
\text { SI }+\mathrm{M}\end{array}$ & $\begin{array}{l}0.750 \\
0.000^{*} \\
0.009^{*}\end{array}$ \\
\hline SI & $274.17 \pm 54.8$ & $\begin{array}{l}\text { Control } \\
\text { MT } \\
\text { SI + M }\end{array}$ & $\begin{array}{l}0.000^{*} \\
0.000^{*} \\
0.010^{*}\end{array}$ & $71.85 \pm 10$ & $\begin{array}{l}\text { Control } \\
\text { MT } \\
\text { SI + M }\end{array}$ & $\begin{array}{l}0.000^{*} \\
0.000^{*} \\
0.000^{*}\end{array}$ & $26.38 \pm 2.96$ & $\begin{array}{l}\text { Control } \\
\mathrm{MT} \\
\mathrm{SI}+\mathrm{M}\end{array}$ & $\begin{array}{l}0.000 * \\
0.000 * \\
0.000 *\end{array}$ \\
\hline $\mathrm{SI}+\mathrm{MT}$ & $413.62 \pm 39.32$ & $\begin{array}{l}\text { Control } \\
\text { MT } \\
\text { SI }\end{array}$ & $\begin{array}{l}0.306 \\
0.276 \\
0.010^{*}\end{array}$ & $122.86 \pm 8.65$ & $\begin{array}{l}\text { Control } \\
\text { MT } \\
\text { SI }\end{array}$ & $\begin{array}{l}0.001^{*} \\
0.020^{*} \\
0.000^{*}\end{array}$ & $37.5 \pm 5.37$ & $\begin{array}{l}\text { Control } \\
\text { MT } \\
\text { SI }\end{array}$ & $\begin{array}{l}0.000 * \\
0.009 * \\
0.000 *\end{array}$ \\
\hline
\end{tabular}

GTh: Granulosa Thickness.

\section{Discussion}

Social isolation is associated with increased oxidative stress and decreased antioxidant capacity [9]. The disturbed oxidant/antioxidant balance results in deleterious effects on the ovary including defective quality of follicles and decrease in progesterone production, which eventually weaken the ovarian reproductive functions [10]. The current study investigated the harmful effect of SI on the ovary of rats and the possible protective role of MT.

The present work demonstrated insignificant difference in the body weight and ovary weight between different groups. These results were in agreement with Aydin et al. [22] . Contrary, Arabameri et al. [23] illustrated significant decrease in body weight in SI group (pups separated from their mothers) compared to control group, while the treated group (received propolis, antioxidant) exhibited significantly increased body weight compared to the stress group.

In the present study, significant increase in the level of MDA in the ovarian tissue was found in SI group compared to control and MT groups, indicating high level of the noxious ROS. This finding was in agreement with Furat Rencber et al. [24], who demonstrated increased MDA caused by another cause of oxidative stress on the ovary, which is Poly Cystic Ovary Syndrome (PCOS). The current study also demonstrated significant decrease in the activity of SOD in SI group in comparison to control and MT groups. The role of SOD as a pivotal regulator of intracellular concentrations of ROS is well known [25]. Our results were in accordance with Arabameri et al. [23], who studied the effect of another psychological stressor (separation of pups from their mothers) on the ovary.

The role of MT as an antioxidant could be explained by its ability to eliminate free radicals, decrease ROS synthesis and enhance gene expression of other antioxidants and hence preventing damage caused by oxidative stress [26,27]. Regarding the role of MT on the ovary, it is important for oocyte maturation and lutinization. It also reduces intrafollicular oxidative damage and increases the possibility of fertilization and pregnancy [28]. In the present study, the ameliorative effect of MT was confirmed by the significant increase in SOD and decrease in MDA levels in SI + MT group compared to SI group indicating improvement of the antioxidant capacity. Similar results were reported by Aydogan et al. [9] and Ma et al. [29]

In the current study, SIRT1 gene expression showed significant increase in SI group compared to control and MT groups. These data were in accordance with Alcendor et al. [30], who reported a (4-fold) upregulation of SIRT1 in response to oxidative stress in the heart. These results could be explained by the exposure to mild/short term oxidative stress which induces SIRT1 expression as a compensatory mechanism [31]. Contrary, severe / long term oxidative stress resulted in low SIRT1 expression in human monocytes $[\mathbf{3 2}, 33]$. Significant decrease in SIRT1 expression in response to long duration oxidative stress (PCOS) was illustrated by Furat Rencber et al. [24]. SIRT1 expression showed significant decrease in SI + MT group compared to SI group. These findings indicated the improvement of oxidative stress in SI + MT group achieved by MT administration. 
In the present study, light microscopic examination of ovarian follicles from SI group illustrated degenerative changes in the form of shrunken granulosa cells with pyknotic nuclei, cytoplasmic vacuolation, rarefaction of the cytoplasm of the oocytes and congested blood vessels around corpora lutea. These findings were in accordance with Furat Rencber et al. [24], who studied the effect of oxidative stress on the ovary mediated by PCOS. Those authors reported also an increase in the level of MDA, which confirmed the harmful effects of increased oxidative stress.

Light microscopic examination of SI + MT group revealed improvement in the histological architecture of the ovary. The granulosa cells were apparently normal and the follicles exhibited regular oocytes, which were surrounded by intact zona pellucida, however, the granulosa cells had occasionally pyknotic nuclei. The corpora lutea were surrounded by non-congested blood vessels and the granulosa lutein cells were apparently normal, apart from few vacuoles. These findings were in agreement with Gül et al. [34], who studied the protective effect of MT against oxidative damage induced by tetrachlorodibenzo-p-dioxin (TCDD) in rat ovary.

In SI group, our study demonstrated noticeable ultrastructural changes of granulosa cells in the form of irregular indented nuclei with dissolution of chromatin and apoptotic bodies. Similar results were reported by Wan et al. [35], who studied the effect of another cause of oxidative stress on the ovary (cadmium administration). Expansion of the intercellular spaces between granulosa cells, heterolysosomes and swollen mitochondria were also seen in SI group. These findings were comparable to the results of Furat Rencber et al. [24], who reported these changes in the PCOS group in their work. An increased lipid droplets was another obvious alteration encountered in the SI group of our study. These results were comparable to those recorded by Shi et al. [10], who attributed this change to increased oxidative stress and deficient antioxidant capacity caused by ozone exposure.

Improvement of the previously mentioned ultrastructural changes was observed in SI + MT group in this work. This was evident by regular nuclei and intact mitochondria, ribosomes, welldeveloped rough endoplasmic reticulum. However, few granulosa cells showed swollen mitochondria, lysosomes and expanded intercellular spaces. Comparable improvement was obtained in MT treated group of a previous work carried out by Gül et al. [34].
Morphometric results of the present work reveled significant decrease of the mean antral follicle diameter, granulosa and theca thickness in SI group compared to control and MT groups, indicating the harmful effect of SI on the ovary. In SI + MT group, there was significant increase in these parameters compared to SI group. This improvement confirmed the ameliorative effect of administration of MT concomitantly with SI. In agreement to our findings, Ahmadi et al. [20] demonstrated a decrease in follicle diameter in PCOS group (known by its oxidative stress) with an increase in follicle diameter with MT treatment.

\section{Conclusion:}

This study demonstrated the deleterious effects of SI on the ovary evident by the significant structural changes encountered in light and electron microscopic examination, increased oxidative stress markers and deficient antioxidant capacity as well as increased SIRT1 gene expression. Melatonin administration improved these destructive effects.

\section{Compliance with ethical standards:}

Conflict of interest: The authors declare no conflict of interest.

\section{References}

1- XIA N. and LI H.: Loneliness, Social Isolation, and Cardiovascular Health. Antioxid Redox Signal., 28 (9): 837-51, doi: 10.1089/ars.2017.7312, 2018.

2- REN Q.G., GONG W.G., WANG Y.J., ZHOU Q.D. and ZHANG Z.J.: Citalopram attenuates tau hyperphosphorylation and spatial memory deficit induced by social isolation rearing in middle-aged rats. J. Mol. Neurosci., 56 (1): 145-53, doi: 10.1007/s12031-014-0475-4, 2015.

3- MAKINODAN M., IKAWA D., YAMAMURO K., YAMASHITA Y., TORITSUKA M., KIMOTOO S., et al.: Effects of the mode of re-socialization after juvenile social isolation on medial prefrontal cortex myelination and function. Sci. Rep., 7 (1): 5481-90. doi: 10.1038/s41598017-05632-2, 2017.

4- KHODAIE B., LOTFINIA A.A., AHMADI M., LOTFINIA M., JAFARIAN M., KARIMZADEH F., et al.: Structural and functional effects of social isolation on the hippocam-pus of rats with traumatic brain injury. Behav. Brain Res., 278: 55-65, Doi 10.1016/j.bbr.2014.09.034, 2015.

5- VALTORTA N.K., KANAAN M., GILBODY S., RONZI S. and HANRATTY B.: Loneliness and social isolation as risk factors for coronary heart disease and stroke: Systematic review and meta-analysis of longitudinal observational studies. Heart, 102 (13): 1009-16, doi: 10.1136/heartjnl-2015-308790, 2016.

6- SERRA M., PISU M.G., LITTERA M., PAPI G., SANNA E., TUVERI F., et al.: Social isolation-induced decreases in both the abundance of neuroactive steroids and GABA 
receptor function in rat brain. J. Neurochem., 75: 73240, 2000.

7- ZANIER-GOMES P.H., De ABREU SILVA T.E., ZANETTI G.C., BENATI É.R., PINHEIRO N.M., MURTA B.M., et al.: Depressive behavior induced by social isolation of predisposed female rats. Physiol. Behav., 151: 292-7, Doi: 10. 101 6/j.physbeh.2015.07.026, 2015.

8- HEIM C. and NEMEROFF C.B.: The role of childhood trauma in the neurobiology of mood and anxiety disorders: Preclinical and clinical studies. Biol. Psychiatry, 49: 102339, 2001.

9- AYDOGAN S., ASCIOGLU M. and COMU F.M.: Consequences of Social Isolation in Rats on Their Antioxidant Defense System and Erythrocyte Deformability. Erciyes Medical Journal, 31 (1): 009-014, 2009.

10- SHI L., ZHANG J., LAI Z., TIAN Y., FANG L., WU M., et al.: Long-Term Moderate Oxidative Stress Decreased Ovarian Reproductive Function by Reducing Follicle Quality and Progesterone Production. PLoS One, 11 (9): e0162194. doi: 10.1371/journal.pone.0162194, 2016.

11-NAKAGAWA T. and GUARENTE L.: Sirtuins at a glance. J. Cell Sci., 124: 833-8, 2011.

12- SINGH C.K., CHHABRA G., NDIADAYE M.A., GARCIA-PETERSON L.M., MACK N.J. and AHMAD N.: The Role of Sirtuins in Antioxidant and Redox Signaling. Antioxid Redox Signal., 28 (8): 643-61, doi: 10.1089/ ars.2017.7290, 2018.

13-HACISEVKI A. and BABA B.: An Overview of Melatonin as an Antioxidant Molecule: A Biochemical Approach. In book: Melatonin-Molecular Biology, Clinical and Pharmaceutical Approaches. Doi: 10.5772/intechopen. 79421, 2018.

14- NASIRAEI-MOGHADAM S.N., PARIVAR K., AHMADIANI A., MOVAHHEDIN M. and VAEEZ MAHDAVI M.R.: Protective Effect of Melatonin against InequalityInduced Damages on Testicular Tissue and Sperm Parameters. Int. J. Fertil Steril., 7 (4): 313-22, 2014.

15- BULTER T.R., CARTER E. and WEINTER J.L.: Adolescent social isolation does not lead to persistent increases in anxiety-like behavior or ethanol intake in female longevans rats. Alcohol. Clin. Exp. Res., 38 (8): 2199-207, 2014.

16- TRIPPLE T. and ROGERS L.: Methods for the Determination of Plasma or Tissue Glutathione Levels. Developmental Toxicology, 315-24, doi: 10.1007/978-1-61779867-2_20, 2012.

17- WEYDERT C.J. and CULLEN J.J.: Measurement of superoxide dismutase, catalase and glutathione peroxidase in cultured cells and tissue. Nat. Protoc., 5 (1): 51-66, doi: 10. 103 8//nprot.2009.197, 2010.

18-BANCROFT J.D. and GAMBLE M.: Theory and practice of histological techniques. 6 th ed. Philadelphia: Churchill Livingstone, 2008.

19- HAYAT M.A.: Principles of techniques of electron microscopy: Biological application. 4 th ed., Cambridge University Press, United Kingdom, pp.: 4-100, 2000.

20- AHMADI M., ROSTAMZADEH A., FATHU F., MOHAMMADI M. and REZAIEA M.J.: The effect of Mela- tonin on histological changes of ovary in induced polycystic ovary syndrome model in mice. Middle East Fertil Soc. J., 22 (4): 255-9, 2017.

21- LEFEVRE P.L.C., BERGER R.G., ERNEST S.R., GAERTNER D.W., RAWN D.F.K., WADE M.G., et al.: Exposure of Female Rats to an Environmentally Relevant Mixture of Brominated Flame Retardants Targets the Ovary, Affecting Folliculogenesis and Steroidogenesis. Biol Reprod. 94 (1): 9, doi: 10.1095/biolreprod.115.134452, 2016.

22- AYDIN V., ÖMEROGLU S., KARTAL B., CO SKUNAKCCAY N., AKARCA-DIZAKAR S.Ö., TÜRKO GLU I, et al.: The Effects of Antioxidant Melatonin on Rat Ovary Neonatal Exposure to Bisphenol A. Duzce Medical Journal, 19 (2): 33-7, 2017.

23- ARABAMERI A., SAMENI H. and BANDEGI A.: The effects of propolis extract on ovarian tissue and oxidative stress in rats with maternal separation stress. Int. J. Reprod Biomed., 15 (8): 509-20, 2017.

24- FURAT RENCBER S., KURNAZ OZBEK S., ERALDEMIR C., SEZER Z., KUM T., CEYLAN S., et al.: Effect of resveratrol and metformin on ovarian reserve and ultrastructure in PCOS: An experimental study. J. Ovarian Res., 11 (1): 55. doi: 10.1186/s13048-018-04277, 2018.

25- EL-MISSIRY M.A.: Antioxidant Enzyme. Intech. Open, pp. 9-12, 2012.

26- GAO C., HAN H.B., TIAN X.Z., TAN D.X., WANG L., ZHOU G.B., et al.: Melatonin promotes embryonic development and reduces reactive oxygen species in vitrified mouse 2-cell embryos. J. Pineal. Res., 52 (3): 305-11. doi: 10.1111/j.1600-079X.2011.00944.x, 2012.

27- CRUZ M.H., LEAL C.L., DA CRUZ J.F., TAN D.X. and REITER R.J.: Role of melatonin on production and preservation of gametes and embryos: a brief review. Anim. Reprod Sci., 145 (3-4): 150-60, doi: 10.1016/j.anireprosci. 2014.01.011, 2014.

28- TAMURA H., TAKASAKI A., TAKETANI T., TANABE M., KIZUKA F., LEE L., et al.: Melatonin as a free radical scavenger in the ovarian follicle. Endocr. J., 60 (1): 1-13, 2013.

29- MA M., CHEN X.Y., LI B. and LI X.T.: Melatonin protects premature ovarian insufficiency induced by tripterygium glycosides: Role of SIRT1. Am. J. Transl. Res., 9 (4): 1580-602, 2017.

30- ALCENDOR R.R., GAO S., ZHAI P., ZABLOCKI D., HOLLE E., YU X., et al.: Sirt1 regulates aging and resistance to oxidative stress in the heart. Circ. Res., 100 (10): 1512-21, 2007.

31- SANTOS L., ESCANDE C. and DENICOLA A.: Potential Modulation of Sirtuins by Oxidative Stress. Oxid Med. Cell Longev., article ID: 9831825, doi: 10.1155/2016/ 9831825, 2016.

32- YANG Y., FU W., CHEN J., OLASHAW N., ZHANG X., NICOSIA S.V., et al.: SIRT1 sumoylation regulates its deacetylase activity and cellular response to genotoxic stress. Nat. Cell Biol., (11): 1253-62, 2007.

33- De KREUTZENBERG S.V., CEOLOTTO G., PAPPARELLA I., BORTOLUZZI A., SEMPLICINI A., DALLA MAN 
C., et al.: Downregulation of the longevity-associated protein sirtuin 1 in insulin resistance and metabolic syndrome: Potential biochemical mechanisms. Diabetes, 59 (4): 1006-15, doi: 10.2337/db09-1187, 2010.

34- GÜL S., GÜL M. and YIGITCAN B.: Melatonin preserves ovarian tissues of rats exposed to chronic TCDD: An electron microscopic approach to effects of TCDD on ovarian cells. Toxicol. Ind. Health, 34 (4): 228-36. doi: 10.1177/0748233717754174, 2018.

35- WAV N., XU Z., LIU T., MIN Y. and LI S.: Ameliorative Effects of Selenium on Cadmium-Induced Injury in the Chicken Ovary: Mechanisms of Oxidative Stress and Endoplasmic Reticulum Stress in Cadmium-Induced Apoptosis. Biol. Trace Elem Res., 184 (2): 463-73, doi: 10.1007/s12011-017-1193-x, 2018.

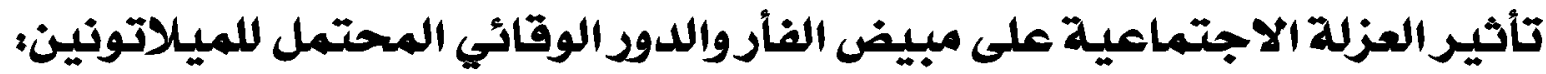

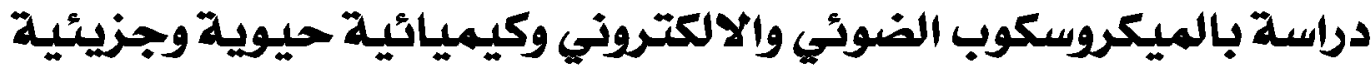

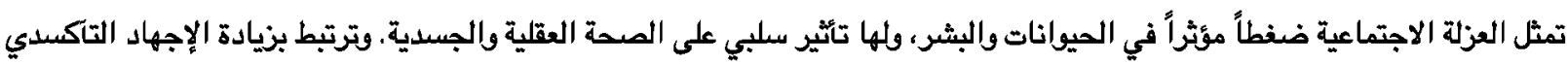
وانخفاض القدرة المضادة للاكسدة. الميلاتونين معوف بخصائصه المضادة للاكسيدة التى تساعل على وقاية الأنسجة من التلف.

$$
\text { يهدف هذا البحث إلى دراسـة التأثير الضار اللعزلة الاجتماعية على مبيض الفأر والدوف الوقائي المحتمل للميلاتونين. }
$$

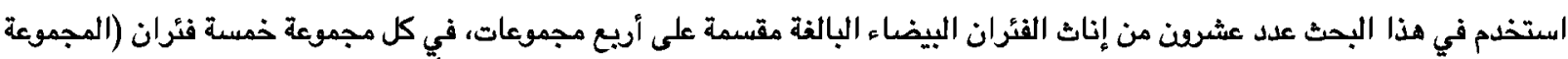
الضابطة، مجموعة تم إعطاؤها الميلاتونين فقط، مجموعة العزلة الاجتماعية، ومجموعة تم عزلها اجتماعياً وإعطائها الميلاتونين).

تم فصص العينات باستخدام صبغتي الهيماتوكسلين والإيوسين وعمل العينات نصف الرقيقة بإستخدام صبغة التولودين الزرقاء وعمل

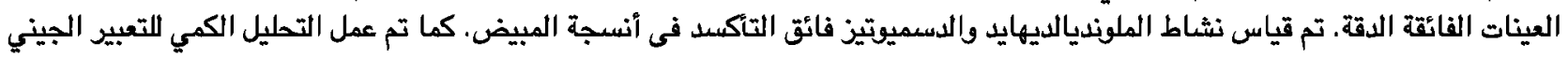

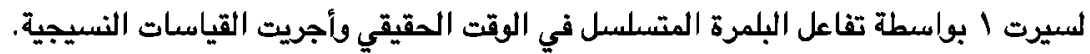

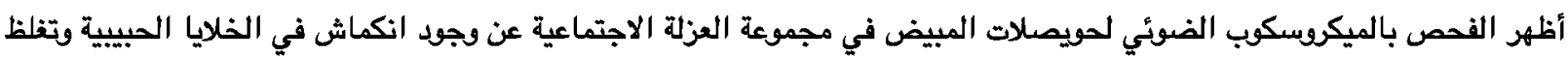
أنويتها ووجود بويضات غير منتظمة. ولوحظ وجود فراغات فى سيتوبلازم الخلايا الحبيية والخلايا الكيسية والخلايا الحبيبية الصفراوية.

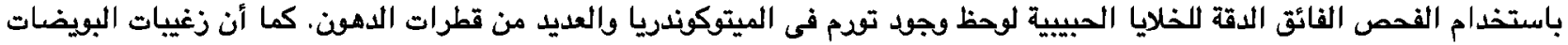

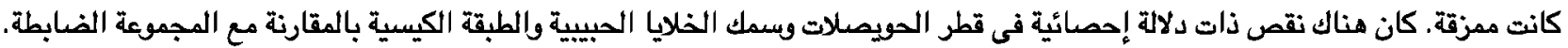

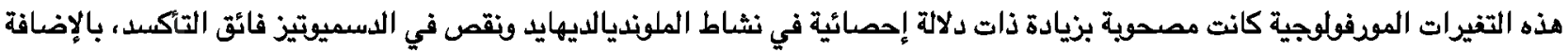

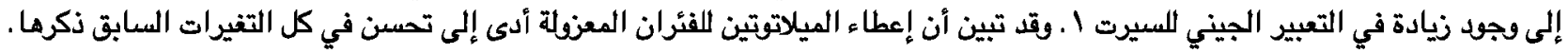
يمكن الاستتاج أن العزلة الاجتماعية قد تسبيت في تفيرات هستولوجية وفائقة الدقة وموفوميترية في مبيض الفئران. كانت هذه التفيرات

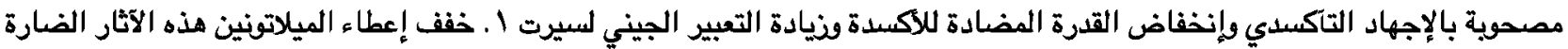

